\title{
Review
}

Zhichao Fan and Xunbin Wei*

\section{In vivo flow cytometry: A powerful optical technology to detect circulating tumor cells and diagnose cancer metastasis in vivo}

\author{
In-vivo-Durchflusszytometrie: Ein leistungsstarkes optisches Verfahren zur Detektion \\ zirkulierender Tumorzellen und zur In-vivo-Diagnose von Metastasen
}

\begin{abstract}
Optical methods have revolutionized medical diagnoses, therapies and research, and have penetrated many medical disciplines for example, tumor diagnosis and treatment. Tumor recurrence and metastasis are the major obstacles for long-term survival in cancer. The metastasis is reported to be correlated with the presence of circulating tumor cells (CTCs) in the vasculature as a consequence of either advanced tumor growth and invasion, or a therapeutic intervention. Thus, CTCs are considered to be important biomarkers for cancer progress and prognosis. The quantification of CTCs is an emerging tool used to diagnose, stratify and monitor patients with metastatic diseases. A number of methods have been developed to detect CTCs, some of which have been applied in clinical diagnosis. However, conventional methods are restricted by invasiveness, lower sensitivity caused by small blood sample volumes, and difficulty in recording the dynamics of CTCs. A novel technique named in vivo flow cytometry (IVFC) can overcome those restrictions. IVFC, which was invented in 2004, can quantitatively monitor circulating cells in vivo, both noninvasively and dynamically. Our work has demonstrated that IVFC has higher specificity and sensitivity than conventional methods. A number of outstanding studies by IVFC have been published on cancer including leukemia, prostate cancer, breast cancer, hepatocellular carcinoma and melanoma, and others. However, there are still numerous remaining questions about cancer metastasis which could be investigated using IVFC. IVFC is a novel and powerful technique to elucidate mechanisms that drive hematogenous metastasis and to monitor the efficacy of cancer therapy. With advances in the technique, IVFC could potentially be used clinically in both cancer diagnosis and treatment. The present review gives an overview of this topic.
\end{abstract}

Keywords: in vivo flow cytometry; hepatocellular carcinoma; circulating tumor cells; biomarker; metastasis.

Zusammenfassung: Optische Methoden haben Diagnostik, Therapie und medizinische Forschung revolutioniert und viele medizinische Disziplinen, wie zum Beispiel die Tumordiagnostik und -behandlung, durchdrungen. Das Wiederauftreten des Primärtumors und die Metastasierung sind die entscheidenden Einflussfaktoren für das langfristige Überleben bei Krebs. Die Entstehung von Metastasen wird mit dem Vorhandensein von zirkulierenden Tumorzellen (circulating tumor cells, CTCs) im Gefäßsystem - entweder als Folge von fortschreitendem Tumorwachstum und Invasion oder einer therapeutischen Intervention - korreliert. D.h. CTCs können als wichtige Biomarker für die Beurteilung der Krankheitsprogression und -prognose dienen. Die Quantifizierung von CTCs stellt somit ein neues Werkzeug zur Diagnose, Stratifizierung und Überwachung von Patienten mit metastasierenden Krebserkrankungen dar. Zur Detektion von CTCs wurde eine Vielzahl von Verfahren entwickelt, von denen einige bereits in der klinischen Diagnostik angewendet werden. Allerdings sind konventionelle Methoden durch ihre Invasivität, die geringere Empfindlichkeit bedingt durch die kleinen Blutprobenvolumina, und Schwierigkeiten bei der Aufzeichnung der Dynamik der CTCs beschränkt. Mit einer neuen Technik, der In-vivo-Durchflusszytometrie (in vivo flow cytometry, IVFC), können diese Beschränkungen überwunden werden. Die IVFC, die 2004 erfunden wurde, kann zirkulierende Zellen in vivo quantitativ überwachen, und zwar sowohl nicht-invasiv als auch dynamisch. Die Arbeit unserer Forschungsgruppe hat gezeigt, dass die IVFC eine höhere Spezifität und Sensitivität gegenüber herkömmlichen Methoden aufweist. Es wurden eine Reihe von herausragenden Studien zur IVFC bei Krebs, 
u.a. bei Leukämie, Prostatakrebs, Brustkrebs, sowie beim hepatozellulären Karzinom und Melanom, veröffentlicht. Es gibt jedoch noch zahlreiche offene Fragen zu Krebsmetastasen, die mittels IVFC untersucht werden könnten. Die IVFC ist eine neuartige und leistungsfähige Technik, um Mechanismen, die zur hämatogenen Metastasierung führen, zu untersuchen und die Wirksamkeit von Krebstherapien $\mathrm{zu}$ überwachen. Mit weiteren technischen Fortschritten könnte die IVFC potentiell klinisch sowohl zur Krebsdiagnose als auch -behandlung eingesetzt werden. Der vorliegende Beitrag gibt einen Überblick zum Thema.

Schlüsselwörter: In-vivo-Durchflusszytometrie; hepatozelluläres Karzinom; zirkulierende Tumorzellen; Biomarker; Metastasen.

\footnotetext{
*Corresponding author: Xunbin Wei, Med-X Research Institute and School of Biomedical Engineering, Shanghai Jiao Tong University, 1954 Huashan Road, Shanghai 200030, China; Department of Chemistry, Fudan University, 220 Handan Road, Shanghai, 200433, China; and Institutes of Biomedical Sciences, Fudan University, 180 Fenglin Road, Shanghai, 200032, China, e-mail:xwei01@sjtu.edu.cn

Zhichao Fan: Department of Chemistry, Fudan University, 220 Handan Road, Shanghai, 200433, China; Institutes of Biomedical Sciences, Fudan University, 180 Fenglin Road, Shanghai, 200032, China; and Med-X Research Institute and School of Biomedical Engineering, Shanghai Jiao Tong University, 1954 Huashan Road, Shanghai 200030, China
}

\section{Introduction}

Light has been used for treatment of illness for thousands of years. However, it has only been since the invention of the laser about 50 years ago that the potential of light in medicine has really been revealed. Several kinds of optical methods have been used in illness diagnoses, therapies and research, such as endoscopy [1], photodynamic therapy [2] and optical cellular/molecular imaging methods [3]. They have revolutionized medicine and have penetrated most disciplines, for example tumor diagnosis and treatment. Researchers continue to push the boundaries so that tumor diagnoses and treatments are faster, safer, less invasive, more precise, and more effective.

Tumor recurrence and metastasis are the major obstacles for long-term survival in cancer. Hematogenous spreading of circulating tumor cells (CTCs) from the primary tumor is a crucial step in the metastasis cascade, which leads ultimately to the formation of overt metastases [4]. Recent studies have shown that the number of CTCs is an independent predictor of progression-free survival and overall survival in metastatic breast cancer and metastatic colorectal cancer $[5,6]$. However, it remains unclear whether the number of CTCs is associated with disease progression and treatment response in other types of cancer.

It has been more than a century since the seed and soil hypothesis $[7,8]$ was proposed. Here we review the history of the evolvement of this theory and show that CTC, the seed, is an important biomarker for cancer progress and prognosis, especially metastasis, and important to cancer diagnosis $[5,6]$. Many methods based on blood extraction have emerged, some of which have been used in clinic [5, 9-14]. However there are restrictions in those in vitro methods, which could be overcome by a novel technique, the "in vivo flow cytometry" (IVFC) [15-17]. IVFC has enormous advantages in detecting CTCs and the study of cancer metastasis [18-23]. It provides a new horizon in cancer study and clinical diagnosis.

\section{The seed and soil hypothesis}

Metastasis refers to the processes that involve the spread of tumor cells to other tissue or organs, both near to as well as distant to the original site. Then the spreading tumor will grow to form metastatic tumors and lead to a recurrence of the cancer (Figure 1). This phenomenon makes cancer hard to overcome and is the cause of most cancer deaths. Therefore, understanding the pathogenesis of metastasis on the systemic, cellular and molecular levels are important goals of cancer research.

It has been more than a century since Paget [7] proposed the seed and soil hypothesis to describe the mechanism by which cancer spreads or metastasizes throughout

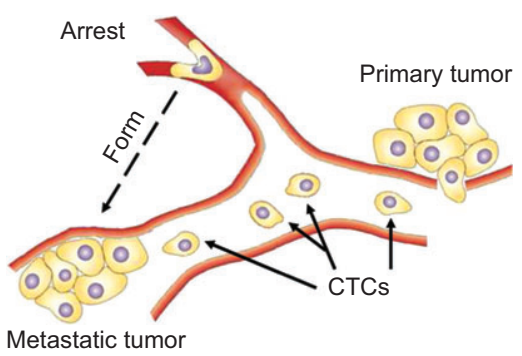

Figure 1 The processes of cancer metastasis. Tumor cells invade through the tumor border and blood vessel wall to form circulating tumor cells. CTCs cruise in the circulating system. Most of them undergo apoptosis or are cleared by immune system. Only a small fraction of CTCS can adhere to the vessel wall in distant organs and can generate secondary tumors, which are called metastases. 
the body. This hypothesis is the most popular theory to explain the mechanism of metastasis. In Paget's studies, he was the first to find out that metastasis was not due to chance but that certain tumor cells had specific affinity for the milieu of certain organs. Thus, he visualized the spreading tumor cells as "seeds" and targeting organ as "soil". He concluded that metastases formed only when the seed and soil were compatible.

In 1929, Ewing [24] challenged the hypothesis and considered metastasis to be purely due to mechanical factors, such as the structure of the blood vessels. Since the 1970s, the selective characteristics of metastasis have been demonstrated [25-27]. In the past few decades more evidence has emerged regarding the interactions between CTCs (the "seeds") and specific organ's microenvironment (the "soil") [27, 28]. Selective metastasis is influenced by the characters of both the seeds [28-30] and the soil [31, 32]. For example, there are complex interactions between leukemia and the microenvironment of bone marrow in the process of metastasis [19, 33].

In 2003, Fidler [8] amended this hypothesis accordingly. In his opinion, the "seed and soil" hypothesis consists of three principles:

- First of all, tumors (both primary tumor and metastases) consist of both tumor cells and host cells, which include epithelial cells, fibroblasts, endothelial cells and infiltrating leukocytes. Moreover, tumors are biologically heterogeneous and contain genotypically and phenotypically diverse subpopulations of tumor cells, each of which have the potential to complete some steps in the metastatic process, but not all.

- Secondly, the process of metastasis is selective for tumor cells. The successful metastatic cell (the "seed") must be proficient in all events which include invasion, embolization, survival in the circulation, arrest in a distant capillary bed, and extravasation into and multiplication within the organ parenchyma, rather than just a few. Although some of the steps in this process contain stochastic elements, as a whole metastasis favors the survival and growth of a few subpopulations of cells that preexist within the parent tumor. Thus, metastases can have a clonal origin whereas different metastases can originate from the proliferation of different single cells.

- Thirdly, and perhaps the most important principle for the design of new cancer therapies is that metastases can only develop in specific organs. The microenvironments of different organs (the "soil") are biologically unique. Endothelial cells in the vasculature of different organs express different cellsurface receptors and growth factors that influence the phenotype of metastases that develop there. In other words, the outcome of metastasis depends on multiple interactions ("cross-talk") of metastasizing cells with homeostatic mechanisms, which the tumor cells can usurp.

\section{Circulating tumor cells - the important biomarker for metastasis}

Biomarkers of metastasis are very important in cancer diagnosis, treatments and studies. Investigators have been interested in the search for biomarkers of metastasis for some time [4-6, 9, 34-37]. However, the current routine of clinical manifestation, radiological evaluations, and serum tumor markers are not capable of providing enough information about the ongoing metastasis early enough, or predicting the clinical outcome with high accuracy and reproducibility [4].

As described above, both the seeds and the soil are important to metastasis. CTCs, i.e., "the seeds", are defined as tumor cells originating from either primary sites or metastases and circulating freely in the peripheral blood of patients and are extremely rare in healthy people [38]. CTCs have long been considered a reflection of tumor aggressiveness. Tumor-induced angiogenesis occurs in step with the action of invasion, which gives rise to the possibility that highly invasive but localized tumors may unleash CTCs into peripheral circulation before any bona fide metastases have been established. Highly aggressive CTCs may not only establish metastases in distant organs but are also capable of self-seeding back to their original organs [39]. Testing for CTCs has emerged as a new and promising tool for stratifying and monitoring patients with metastatic disease [11]. A number of currently available CTCs detection platforms have been verified in various clinical settings, which strongly suggest that CTCs detection has enormous potential in assisting malignancy diagnosis, estimating prognosis and monitoring the response of the anticancer therapy [40]. According to previous studies, CTCs count could be used as a potential and powerful biomarker for cancer diagnosis and prognostic prediction $[4,5]$, in e.g., colorectal cancer [41, 42], gastric cancer [43, 44], liver cancer [45], lung cancer [46, 47], breast cancer [5, 6, 9-14], and prostate cancer [48]. 


\section{Conventional methods to detect CTCs}

Conventional methods to detect CTCs are based on the analysis of blood samples and have been used in clinical assays [40]. The methods can be classified into two approaches: (1) immunological assays using monoclonal antibodies directed against histogenic proteins and (2) polymerase chain reaction (PCR)-based molecular assays exploiting tissue-specific transcripts. Before application of the detection technology, most approaches require an enrichment of CTCs. Enrichment can improve the sensitivity and is usually based on density-gradient centrifugation and immunomagnetic procedures [49].

In immunological approaches, a number of monoclonal antibodies are used for protein markers of cancer cells. The most widely used system for immunological assays is called CellSearch $^{\mathrm{TM}}[5,13]$, which has been also used frequently in clinical research. It is an automated immunomagnetic enrichment and staining system. In this approach, CTCs are enriched by ferrofluids coupled to antibodies against an epithelial cell adhesion molecule (EpCAM). EpCAM is a cell adhesion molecule commonly expressed on normal epithelial cells (usually not present in the blood of healthy subjects) and malignant epithelial cells [50, 51]. Furthermore, tumor cells are identified by cytokeratin (cytoskeletal proteins that are specifically expressed in epithelial cells) staining using fluorescent antibodies. Non-specific staining of hematopoietic cells is detected by counterstaining with cluster of differentiation 45 (CD45) (common leukocyte antigen) antibodies. In addition to CellSearch ${ }^{\mathrm{TM}}$, many other immunological assays have been developed. For example, fluorescence activated cell sorting analysis using conventional flow cytometry [18, 23], high throughput CTC chip [52, 53], fiber-optic array scanning technology [54, 55], etc.

PCR assays have been used in CTCs detection since the 1990s [56]. These methods have a higher sensitivity [57]. In all these methods, quantitative real-time PCR (qPCR) has addressed the problem of false-positive signals in noncancer controls [58]. However, in view of the lack of true cancer specific molecular targets, qPCR has become more or less the state-of-the-art quantitative method, allowing the determination of cut-off values of marker transcript numbers in samples of non-cancer controls, by which transcripts can be considered as tumor cell-derived [40].

However, all these conventional methods are limited by invasiveness, lower sensitivity caused by limited blood sample volumes, and the difficulty to record the dynamics of CTCs. As a result noninvasive, more sensitive and dynamic monitoring methods are still needed.

\section{In vivo flow cytometry and CTCs detection}

Optical imaging methods, such as in vivo imaging technology in small animal [59], intravital/endoscopic microscopy $[19,60]$, confocal/multi-photon microscopy, optical coherence tomography [61], and photoacoustic imaging [62], are widely used in cancer diagnosis and research as they have the advantage of being noninvasive, highly sensitive and of high resolution. However, none of the methods is optimized to quantitatively detect changes in the number of circulating cells as IVFC does. IVFC was invented in 2004 [15]. It is a novel technique that can monitor circulating cells in vivo, and combines the advantages of conventional flow cytometry with in vivo confocal microscopy (Figure 2). In this technique the laser is focused on a slit. With imaging guidance, the slit is positioned to cover the natural regions of blood flow which could be arteries, veins or lymphatic vessels (Figure 3). When target cells, which are usually

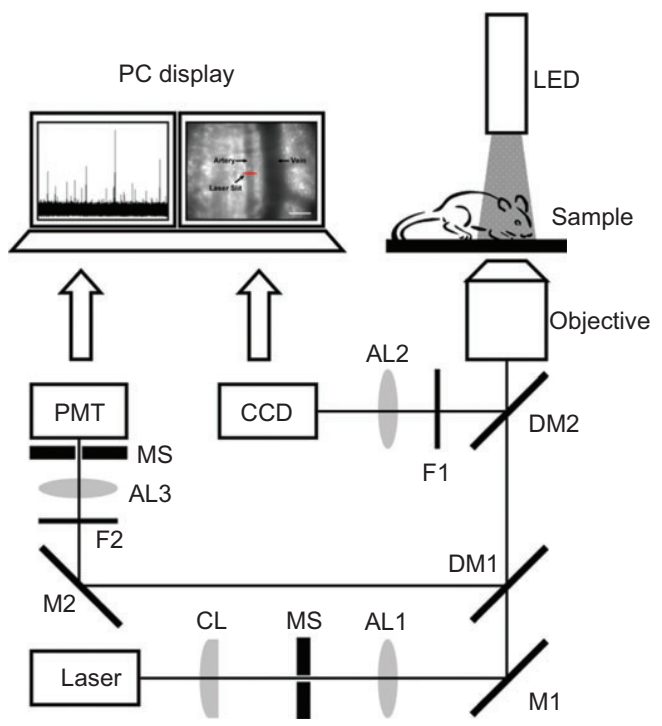

Figure 2 Schematic of in vivo flow cytometer experimental set-up. Laser light $(635 \mathrm{~nm})$ is focused into a slit $(5 \mu \mathrm{m} \times 72 \mu \mathrm{m})$ by a cylindrical lens (CL; focal length, $150 \mathrm{~mm}$ ) and imaged across the selected blood vessel with a microscope objective lens $(40 \times, N A=0.6)$. The fluorescence from excited labeled cells in blood stream is collected by the same microscope objective, directed through the dichromatic mirror DM2, which reflects green light emitting diode (LED) light to image the sample onto a charge coupled device (CCD) camera (reflection $25 \%$, transmission $75 \%$; M/s Edmund Optics), reflected by a second splitter DM1 (transmission $\geq 90 \%$ for $488 \mathrm{~nm}$ and $635 \mathrm{~nm}$; reflection $\geq 90 \%$ for 499-556 nm, 580-622 nm, and 652-755 nm; M/s Semrock), a mirror, and imaged onto a $200 \mu \mathrm{m} \times 3000 \mu \mathrm{m}$ mechanical slit (MS), which is confocal with the excitation slit. F1 and F2: band pass filters (F1: 509-552 nm; F2: 640-690 nm; M/s Semrock). AL1 and AL3: achromatic lenses (focal length, $150 \mathrm{~mm}$ ). AL2: achromatic lens (focal length, $30 \mathrm{~mm}$ ). $M 1$ and $M 2$ : mirrors. 


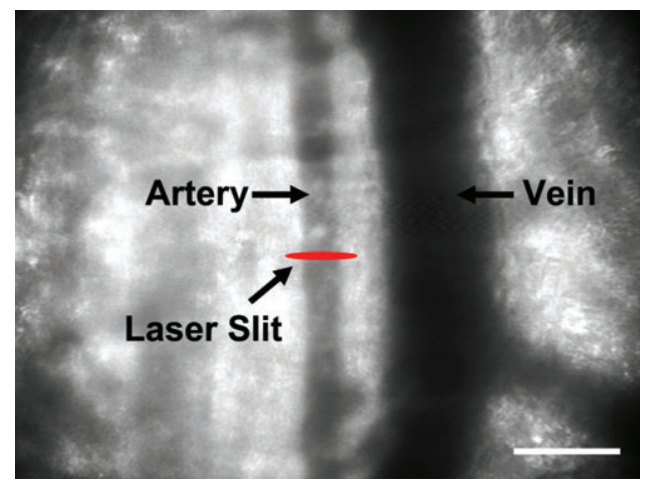

Figure 3 The transillumination image of the microcirculation in a mouse ear was acquired by a real-time CCD camera with a $40 \times$ objective (NA=0.6). A 520-550 nm LED was used to visualize the vessels. A laser slit in the IVFC projects an image across an artery in the mouse ear. The fluorescence signals from the excited cells were recorded. The scale bar is $100 \mu \mathrm{m}$.

labeled with fluorescence, are flowing with the blood and pass the slit, the fluorescence signal is excited and is subsequently detected by a confocused photomultiplier tube. The data can be collected and recorded by computer and analyzed by software (Figure 4). A line-separating method has been used conventionally to derive CTCs counts from the IVFC data [20]. Other optimized methods, such as a wavelet-based method [22], have also been developed in data processing of IVFC. The technique is capable of continuously monitoring the varieties of target cells in circulation, e.g., cancer cells [18-23], hematopoietic stem cells [63, 64], lymphocytes [65, 66], red blood cells [15-17], apoptotic cells [67], and yields quantitative results without affecting the physiology of the subject.

Compared to conventional CTCs detection methods, IVFC has the advantage of noninvasiveness, higher sensitivity and dynamic monitoring. In our opinion, the most important advantage of this technique is dynamic monitoring. The

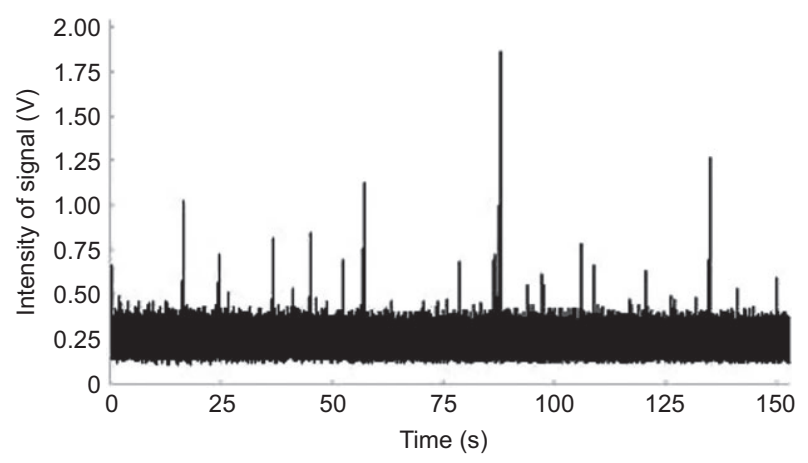

Figure 4 Visualization of digitized IVFC signals of fluorescence labeled circulating tumor cells using software developed on MATLAB platform. acquired real-time information may provide novel insights into tumor progress, metastasis processes and the response to treatment. It can improve our knowledge of tumor metastasis and guide therapeutic schedules.

In 2004, Georgakoudi and her coworkers [20] were the first group to use IVFC to study cancer. They presented the depletion kinetics of injected prostate cancer cells in mice and indicated that IVFC might become a new method for enumerating CTCs. They found out that the depletion kinetics of CTCs showed differences among different tumor cell lines and host animals. This might indicate that metastasis is associated with the characters of both tumor cells and hosts. In addition, the real-time changes of depletion kinetics might provide novel information about tumor metastasis, e.g., real-time processes of CTCs forming, homing or re-emerging. In 2011, Li et al. [22] in our group provided depletion kinetics of injected prostate cancer cells with different metastasis potential. We found out that the CTCs depletion kinetics might be associated with the condition of metastatic sites.

In 2005, Sipkins and her coworkers [19] published important work about IVFC, which firstly used IVFC to study the CTCs homing and the interaction between "seed" and "soil" in tumor metastasis. In this study, they initially used IVFC to evaluate the drug effect to restrain bone marrow metastasis of leukemia. An important pair of molecules for bone marrow metastasis was discovered, namely C-X-C chemokine receptor type 4 (CXCR4) and stromal cellderived factor 1 (SDF-1). The inhibitor of CXCR4 was able to significantly restrain CTC depletion and homing to bone marrow. In this work, IVFC provided important evidence and demonstrated its importance in cancer study. A similar method was used in the studies of multiple myeloma [6870], prostate cancer [22], and others.

Our group focused on liver cancer study using IVFC. We studied the depletion kinetics of injected liver cancer cells with different metastasis potential [21, 22]. However, the injection tumor model, which has been commonly used by many groups before, could not mimic metastasis well. Although it reflected some circulating metastatic characteristics or therapeutic responses of cancer cells, the large number of injected CTCs does not exist in pathologic conditions [71, 72]. Thus, we built an orthotopic hepatocellular carcinoma (HCC) model and combined it with IVFC to study cancer metastasis [23]. It was the first study of CTCs dynamics using a clinically relevant oncology condition by IVFC. Interestingly, we observed significant differences in the CTCs dynamics between orthotopic and subcutaneous models. We also used our model to investigate whether liver resection promoted or restricted hematogenous metastasis in advanced HCC. Both the 
number of CTCs and early metastases decreased significantly after tumor resection. Resection also prominently restricted hematogenous and distant metastases. Importantly, CTCs numbers were correlated with tumor growth in the orthotopic tumor model, including the number and size of distant metastases. Our work has demonstrated that when combined with orthotopic tumor models, the novel IVFC technique offers the capability to elucidate mechanisms that drive hematogenous metastasis and to monitor the efficacy of cancer therapy.

He et al. [18] and Galanzha et al. [73, 74] introduced multiphoton, photoacoustic and photothermal techniques into IVFC. Meanwhile, they used a monoclonal antibody to label and detect CTCs. As reported, they succeeded in detecting rare CTCs in subcutaneous lung cancer or melanoma model. Moreover, Alt et al. [75] designed a retinal flow cytometer which is an improved IVFC and can detect circulating cells in retinal vessels. This technique had a five times higher sensitivity than conventional IVFC and provided a suitable site for detection which could also be used in clinic. These might enable the use of IVFC in clinical diagnosis or therapeutic evaluations.

There are two disadvantages of IVFC which could limit its further applications. Firstly, IVFC when used as an optical method has a limited detection depth. Only superficial vessels, such as vessels in mouse ear or retinal vessels, can be used directly for measurements. An endoscopic IVFC might be useful for the clinical use. Photoacoustic flow cytometry might also be useful in detecting deeper vessels. Secondly, the labeling of target cells is a problem, especially for clinical applications. The specific labeling of various tumor cells currently presents a big challenge for use in medicine, and this limits the applications of IVFC in clinical diagnoses or therapeutic evaluations. Therefore, studies of novel probes which specifically target tumor cells will be significant for further IVFC clinical applications. Moreover, label-free IVFC, which can detect tumor cells without labeling, could also be a promising development.

\section{Discussion}

We describe here the use of IVFC as a noninvasive and continuous method to monitor the dynamics of CTCs in cancer metastasis. Conventional methods such as conventional flow cytometry or methods based on magnetic bead sorting followed by immune-staining and fluorescence imaging [5, 9-14] can quantify CTCs in vitro. However, it is difficult to monitor CTCs dynamics using these methods. In contrast, IVFC has been optimized to quantitatively detect changes in the number of CTCs noninvasively, and can detect rare CTCs by prolonging the time of measurement. In our study [23], IVFC had about $\sim 1.8$-fold higher sensitivity than whole blood analysis by conventional flow cytometry. This improvement may be caused by absence of the loss from extract and treatment of blood sample.

There are three major advantages for IVFC: (1) Noninvasiveness. This advantage might be important to patients in the clinic. Furthermore, for scientific research, this advantage may guarantee the survival of animals compared to conventional methods. (2) Higher sensitivity. Without the processes of blood extraction and sample treatment, the factitious error and sample loss can be avoided. Moreover, the sensitivity of conventional methods is restricted by sample volume. This restriction can be resolved by prolonging IVFC testing time. (3) Dynamic monitoring. IVFC could monitor the CTCc dynamics in real-time and in the same proband, which is, to our knowledge, currently impossible for conventional methods. If by increasing the time points of sampling to approximate real time, the volume of the samples will be restricted by that of the proband's whole blood, and the sensitivity will be greatly compromised.

\section{Conclusion}

In conclusion, the novel IVFC technique offers the possibility of monitoring rare CTCs, elucidate mechanisms that drive hematogenous metastasis and evaluate the efficacy of cancer therapy. IVFC may provide new insights in scientific research and future clinical applications.

Acknowledgments: This work is supported by the National Basic Research Program of China (973 Program, 2011CB910404 and 2012CB966800), China National Natural Science Foundation (30901432 and 30972949), the Chinese Ministry of Education (109056), Program for New Century Excellent Talents in University Award (NCET08-0131), Shanghai Science and Technology Committee (11DZ2211000) and the Fudan University 2010 Excellent Ph.D. Research Foundation.

Received September 12, 2012; revised November 1, 2012; accepted November 7, 2012; previously published December 6, 2012 


\section{References}

[1] Fisher LR, Hasler WL. New vision in video capsule endoscopy: current status and future directions. Nat Rev Gastroenterol Hepatol 2012;9(7):392-405.

[2] Wilson BC, Patterson MS. The physics, biophysics and technology of photodynamic therapy. Phys Med Biol 2008;53(9):R61-109.

[3] Taruttis A, Ntziachristos V. Translational optical imaging. AJR Am J Roentgenol 2012;199(2):263-71.

[4] Sun YF, Yang XR, Zhou J, Qiu SJ, Fan J, Xu Y. Circulating tumor cells: advances in detection methods, biological issues, and clinical relevance. J Cancer Res Clin Oncol 2011;137(8):1151-73.

[5] Cristofanilli M, Budd GT, Ellis MJ, Stopeck A, Matera J, Miller MC, Reuben JM, Doyle GV, Allard WJ, Terstappen LW, Hayes DF. Circulating tumor cells, disease progression, and survival in metastatic breast cancer. N Engl J Med 2004;351(8):781-91.

[6] Cohen SJ, Punt CJ, Iannotti N, Saidman BH, Sabbath KD, Gabrail NY, Picus J, Morse M, Mitchell E, Miller MC, Doyle GV, Tissing H, Terstappen LW, Meropol NJ. Relationship of circulating tumor cells to tumor response, progression-free survival, and overall survival in patients with metastatic colorectal cancer. J Clin Oncol 2008;26(19):3213-21. Erratum in: J Clin Oncol 2009;27(11):1923.

[7] Paget S. The distribution of secondary growths in cancer of the breast. Lancet 1889;133(3421):571-3.

[8] Fidler IJ. The pathogenesis of cancer metastasis: the 'seed and soil' hypothesis revisited. Nat Rev Cancer 2003;3(6):453-8.

[9] Cristofanilli M, Hayes DF, Budd GT, Ellis MJ, Stopeck A, Reuben JM, Doyle GV, Matera J, Allard WJ, Miller MC, Fritsche HA, Hortobagyi GN, Terstappen LW. Circulating tumor cells: a novel prognostic factor for newly diagnosed metastatic breast cancer. J Clin Oncol 2005;23(7):1420-30.

[10] Müller V, Riethdorf S, Rack B, Janni W, Fasching PA, Solomayer E, Aktas B, Kasimir-Bauer S, Zeitz J, Pantel K, Fehm T, DETECT study group. Prospective evaluation of serum tissue inhibitor of metalloproteinase 1 and carbonic anhydrase IX in correlation to circulating tumor cells in patients with metastatic breast cancer. Breast Cancer Res 2011;13(4):R71.

[11] Andreopoulou E, Cristofanilli M. Circulating tumor cells as prognostic marker in metastatic breast cancer. Expert Rev Anticancer Ther 2010;10(2):171-7.

[12] Hayes DF, Cristofanilli M, Budd GT, Ellis MJ, Stopeck A, Miller MC, Matera J, Allard WJ, Doyle GV, Terstappen LW. Circulating tumor cells at each follow-up time point during therapy of metastatic breast cancer patients predict progression-free and overall survival. Clin Cancer Res 2006;12(14 Pt 1):4218-24.

[13] Riethdorf S, Fritsche H, Müller V, Rau T, Schindlbeck C, Rack B, Janni W, Coith C, Beck K, Jänicke F, Jackson S, Gornet T, Cristofanilli M, Pantel K. Detection of circulating tumor cells in peripheral blood of patients with metastatic breast cancer: a validation study of the CellSearch system. Clin Cancer Res 2007;13(3):920-8.

[14] Bidard FC, Vincent-Salomon A, Sigal-Zafrani B, Diéras V, Mathiot C, Mignot L, Thiery JP, Sastre-Garau X, Pierga JY. Prognosis of women with stage IV breast cancer depends on detection of circulating tumor cells rather than disseminated tumor cells. Ann Oncol 2008;19(3):496-500.
[15] Novak J, Georgakoudi I, Wei X, Prossin A, Lin CP. In vivo flow cytometer for real-time detection and quantification of circulating cells. Opt Lett 2004;29(1):77-9.

[16] Novak J, Puoris'haag M. Two-color, double-slit in vivo flow cytometer. Opt Lett 2007;32(20):2993-5.

[17] Zhong CF, Tkaczyk ER, Thomas T, Ye JY, Myc A, Bielinska AU, Cao Z, Majoros I, Keszler B, Baker JR, Norris TB. Quantitative two-photon flow cytometry - In vitro and in vivo. J Biomed Opt 2008;13(3):034008.

[18] He W, Wang H, Hartmann LC, Cheng JX, Low PS. In vivo quantitation of rare circulating tumor cells by multiphoton intravital flow cytometry. Proc Natl Acad Sci USA 2007;104(28):11760-5.

[19] Sipkins DA, Wei X, Wu JW, Runnels JM, Côté D, Means TK, Luster AD, Scadden DT, Lin CP. In vivo imaging of specialized bone marrow endothelial microdomains for tumour engraftment. Nature 2005;435(7044):969-73.

[20] Georgakoudi I, Solban N, Novak J, Rice WL, Wei X, Hasan T, Lin CP. In vivo flow cytometry: a new method for enumerating circulating cancer cells. Cancer Res 2004;64(15):5044-7.

[21] Li Y, Fan Z, Guo J, Liu G, Tan X, Wang C, Gu Z, Wei X. Circulation times of hepatocellular carcinoma cells by in vivo flow cytometry. Chin Opt Lett 2010;8(10):953-6.

[22] Li Y, Guo J, Wang C, Fan Z, Liu G, Wang C, Gu Z, Damm D, Mosig A, Wei X. Circulation times of prostate cancer and hepatocellular carcinoma cells by in vivo flow cytometry. Cytometry A 2011;79(10):848-54.

[23] Fan ZC, Yan J, Liu GD, Tan XY, Weng XF, Wu WZ, Zhou J, Wei XB. Real-time monitoring of rare circulating hepatocellular carcinoma cells in an orthotopic model by in vivo flow cytometry assesses resection on metastasis. Cancer Res 2012;72(10):2683-91.

[24] Ewing J. Neoplastic disease: a treatise on tumors. Philadelphia: W.B. Saunders Co; 1922.

[25] Hart IR, Fidler IJ. Role of organ selectivity in the determination of metastatic patterns of B16 melanoma. Cancer Res 1980;40(7):2281-7.

[26] Sugarbaker EV. Cancer metastasis: a product of tumor-host interactions. Curr Probl Cancer 1979;3(7):1-59.

[27] Weiss L. Metastasis of cancer: a conceptual history from antiquity to the 1990s. Cancer Metastasis Rev 2000;19 (3-4):193-383.

[28] Fidler IJ. The organ microenvironment and cancer metastasis. Differentiation 2002;70(9-10):498-505.

[29] Fidler IJ. Critical factors in the biology of human cancer metastasis: twenty-eighth G.H.A. Clowes memorial award lecture. Cancer Res 1990;50(19):6130-8.

[30] Fidler IJ, Talmadge JE. Evidence that intravenously derived murine pulmonary melanoma metastases can originate from the expansion of a single tumor cell. Cancer Res 1986;46(10):5167-71.

[31] Pasqualini R, Ruoslahti E. Organ targeting in vivo using phage display peptide libraries. Nature 1996;380(6572):364-6.

[32] Uehara H, Kim SJ, Karashima T, Shepherd DL, Fan D, Tsan R, Killion JJ, Logothetis C, Mathew P, Fidler IJ. Effects of blocking platelet-derived growth factor-receptor signaling in a mouse model of experimental prostate cancer bone metastases. J Natl Cancer Inst 2003;95(6):458-70. 
[33] Colmone A, Amorim M, Pontier AL, Wang S, Jablonski E, Sipkins DA. Leukemic cells create bone marrow niches that disrupt the behavior of normal hematopoietic progenitor cells. Science 2008;322(5909):1861-5.

[34] Bai DS, Dai Z, Zhou J, Liu YK, Qiu SJ, Tan CJ, Shi YH, Huang C, Wang Z, He YF, Fan J. Capn4 overexpression underlies tumor invasion and metastasis after liver transplantation for hepatocellular carcinoma. Hepatology 2009;49(2):460-70.

[35] Bohn OL, Nasir I, Brufsky A, Tseng GC, Bhargava R, MacManus K, Chivukula M. Biomarker profile in breast carcinomas presenting with bone metastasis. Int J Clin Exp Pathol 2009;3(2):139-46.

[36] Xue H, Lü B, Zhang J, Wu M, Huang Q, Wu Q, Sheng H, Wu D, $\mathrm{Hu}$ J, Lai M. Identification of serum biomarkers for colorectal cancer metastasis using a differential secretome approach. J Proteome Res 2010;9(1):545-55.

[37] Cheng J, Xie HY, Xu X, Wu J, Wei X, Su R, Zhang W, Lv Z, Zheng S, Zhou L. NDRG1 as a biomarker for metastasis, recurrence and of poor prognosis in hepatocellular carcinoma. Cancer Lett 2011;310(1):35-45.

[38] Allard WJ, Matera J, Miller MC, Repollet M, Connelly MC, Rao C, Tibbe AG, Uhr JW, Terstappen LW. Tumor cells circulate in the peripheral blood of all major carcinomas but not in healthy subjects or patients with nonmalignant diseases. Clin Cancer Res 2004;10(20):6897-904.

[39] Kim MY, Oskarsson T, Acharyya S, Nguyen DX, Zhang XH, Norton L, Massagué J. Tumor self-seeding by circulating cancer cells. Cell 2009;139(7):1315-26.

[40] Pantel K, Brakenhoff RH, Brandt B. Detection, clinical relevance and specific biological properties of disseminating tumour cells. Nat Rev Cancer 2008;8(5):329-40.

[41] Cohen SJ, Punt CJ, Iannotti N, Saidman BH, Sabbath KD, Gabrail NY, Picus J, Morse MA, Mitchell E, Miller MC, Doyle GV, Tissing H, Terstappen LW, Meropol NJ. Prognostic significance of circulating tumor cells in patients with metastatic colorectal cancer. Ann Oncol 2009;20(7):1223-9.

[42] Matsusaka S, Suenaga M, Mishima Y, Kuniyoshi R, Takagi K, Terui Y, Mizunuma N, Hatake K. Circulating tumor cells as a surrogate marker for determining response to chemotherapy in Japanese patients with metastatic colorectal cancer. Cancer Sci 2011;102(6):1188-92.

[43] Yie SM, Lou B, Ye SR, Cao M, He X, Li P, Hu K, Rao L, Wu SM, Xiao HB, Gao E. Detection of survivin-expressing circulating cancer cells (CCCs) in peripheral blood of patients with gastric and colorectal cancer reveals high risks of relapse. Ann Surg Oncol 2008;15(11):3073-82.

[44] Cao W, Yang W, Li H, Lou G, Jiang J, Geng M, Xi W, Ren R, Qu Q, Jin X, Zhu Y, Jin Y. Using detection of survivin-expressing circulating tumor cells in peripheral blood to predict tumor recurrence following curative resection of gastric cancer. J Surg Oncol 2011;103(2):110-5.

[45] Vona G, Estepa L, Béroud C, Damotte D, Capron F, Nalpas B, Mineur A, Franco D, Lacour B, Pol S, Bréchot C, PaterliniBréchot P. Impact of cytomorphological detection of circulating tumor cells in patients with liver cancer. Hepatology 2004;39(3):792-7.

[46] Krebs MG, Sloane R, Priest L, Lancashire L, Hou JM, Greystoke A, Ward TH, Ferraldeschi R, Hughes A, Clack G, Ranson M, Dive C, Blackhall FH. Evaluation and prognostic significance of circulating tumor cells in patients with non-small-cell lung cancer. J Clin Oncol 2011;29(12):1556-63.
[47] Hofman V, Bonnetaud C, Ilie MI, Vielh P, Vignaud JM, Fléjou JF, Lantuejoul S, Piaton E, Mourad N, Butori C, Selva E, Poudenx M, Sibon S, Kelhef S, Vénissac N, Jais JP, Mouroux J, Molina TJ, Hofman P. Preoperative circulating tumor cell detection using the isolation by size of epithelial tumor cell method for patients with lung cancer is a new prognostic biomarker. Clin Cancer Res 2011;17(4):827-35.

[48] Coumans FA, Doggen CJ, Attard G, de Bono JS, Terstappen LW. All circulating EpCAM+CK+CD45- objects predict overall survival in castration-resistant prostate cancer. Ann Oncol 2010;21(9):1851-7.

[49] Paterlini-Brechot P, Benali NL. Circulating tumor cells (CTC) detection: clinical impact and future directions. Cancer Lett 2007;253(2):180-204.

[50] Diamandis EP, Fritsche HA, Lilja H, Chan DW, Schwartz MK, editors. Tumor markers: physiology, pathobiology, technology and clinical applications. Washington: AACC Press; 2002.

[51] Litvinov SV, van Driel W, van Rhijn CM, Bakker HA, van Krieken H, Fleuren GJ, Warnaar SO. Expression of Ep-CAM in cervical squamous epithelia correlates with an increased proliferation and the disappearance of markers for terminal differentiation. Am J Pathol 1996;148(3):865-75.

[52] Uhr JW. Cancer diagnostics: one-stop shop. Nature 2007;450(7173):1168-9.

[53] Nagrath S, Sequist LV, Maheswaran S, Bell DW, Irimia D, Ulkus L, Smith MR, Kwak EL, Digumarthy S, Muzikansky A, Ryan P, Balis UJ, Tompkins RG, Haber DA, Toner M. Isolation of rare circulating tumour cells in cancer patients by microchip technology. Nature 2007;450(7173):1235-9.

[54] Hsieh HB, Marrinucci D, Bethel K, Curry DN, Humphrey M, Krivacic RT, Kroener J, Kroener L, Ladanyi A, Lazarus N, Kuhn P, Bruce RH, Nieva J. High speed detection of circulating tumor cells. Biosens Bioelectron 2006;21(10):1893-9.

[55] Krivacic RT, Ladanyi A, Curry DN, Hsieh HB, Kuhn P, Bergsrud DE, Kepros JF, Barbera T, Ho MY, Chen LB, Lerner RA, Bruce RH. A rare-cell detector for cancer. Proc Natl Acad Sci USA 2004;101(29):10501-4.

[56] Smith B, Selby P, Southgate J, Pittman K, Bradley C, Blair GE. Detection of melanoma cells in peripheral blood by means of reverse transcriptase and polymerase chain reaction. Lancet 1991;338(8777):1227-9.

[57] Brakenhoff RH, Stroomer JG, ten Brink C, de Bree R, Weima SM, Snow GB, van Dongen GA. Sensitive detection of squamous cells in bone marrow and blood of head and neck cancer patients by $\mathrm{E} 48$ reverse transcriptase-polymerase chain reaction. Clin Cancer Res 1999;5(4):725-32.

[58] van Houten VM, Tabor MP, van den Brekel MW, Denkers F, Wishaupt RG, Kummer JA, Snow GB, Brakenhoff RH. Molecular assays for the diagnosis of minimal residual head-and-neck cancer: methods, reliability, pitfalls, and solutions. Clin Cancer Res 2000;6(10):3803-16.

[59] Yan H, Wang L, Wang J, Weng X, Lei H, Wang X, Jiang L, Zhu J, Lu W, Wei X, Li C. Two-order targeted brain tumor imaging by using an optical/paramagnetic nanoprobe across the blood brain barrier. ACS Nano 2012;6(1):410-20.

[60] Sokolov K, Sung KB, Collier T, Clark A, Arifler D, Lacy A, Descour M, Richards-Kortum R. Endoscopic microscopy. Dis Markers 2002;18(5-6):269-91.

[61] Sun C, Nolte F, Cheng KH, Vuong B, Lee KK, Standish BA, Courtney B, Marotta TR, Mariampillai A, Yang VX. In vivo 
feasibility of endovascular Doppler optical coherence tomography. Biomed Opt Express 2012;3(10):2600-10.

[62] Wang X, Pang Y, Ku G, Xie X, Stoica G, Wang LV. Noninvasive laser-induced photoacoustic tomography for structural and functional in vivo imaging of the brain. Nat Biotechnol 2003;21(7):803-6.

[63] Boutrus S, Greiner C, Hwu D, Chan M, Kuperwasser C, Lin CP, Georgakoudi I. Portable two-color in vivo flow cytometer for real-time detection of fluorescently-labeled circulating cells. J Biomed Opt 2007;12(2):020507.

[64] Lo Celso C, Fleming HE, Wu JW, Zhao CX, Miake-Lye S, Fujisaki J, Côté D, Rowe DW, Lin CP, Scadden DT. Live-animal tracking of individual haematopoietic stem/progenitor cells in their niche. Nature 2009;457(7225):92-6.

[65] Fan Z, Spencer JA, Lu Y, Pitsillides CM, Singh G, Kim P, Yun SH, Toxavidis V, Strom TB, Lin CP, Koulmanda M. In vivo tracking of 'color-coded' effector, natural and induced regulatory T cells in the allograft response. Nat Med 2010;16(6):718-22.

[66] Lee H, Alt C, Pitsillides CM, Puoris'haag M, Lin CP. In vivo imaging flow cytometer. Opt Express 2006;14(17): 7789-800.

[67] Wei X, Sipkins DA, Pitsillides CM, Novak J, Georgakoudi I, Lin CP. Real-time detection of circulating apoptotic cells by in vivo flow cytometry. Mol Imaging 2005;4(4):415-6.

[68] Alsayed Y, Ngo H, Runnels J, Leleu X, Singha UK, Pitsillides CM, Spencer JA, Kimlinger T, Ghobrial JM, Jia X, Lu G, Timm M, Kumar A, Côté D, Veilleux I, Hedin KE, Roodman GD, Witzig TE, Kung AL, Hideshima T, Anderson KC, Lin CP, Ghobrial IM. Mechanisms of regulation of CXCR4/SDF-1 (CXCL12)dependent migration and homing in multiple myeloma. Blood 2007;109(7):2708-17.
[69] Azab AK, Runnels JM, Pitsillides C, Moreau AS, Azab F, Leleu X, Jia X, Wright R, Ospina B, Carlson AL, Alt C, Burwick N, Roccaro AM, Ngo HT, Farag M, Melhem MR, Sacco A, Munshi NC, Hideshima T, Rollins BJ, Anderson KC, Kung AL, Lin CP, Ghobrial IM. CXCR4 inhibitor AMD3100 disrupts the interaction of multiple myeloma cells with the bone marrow microenvironment and enhances their sensitivity to therapy. Blood 2009;113(18):4341-51.

[70] Runnels JM, Carlson AL, Pitsillides C, Thompson B, Wu J, Spencer JA, Kohler JM, Azab A, Moreau AS, Rodig SJ, Kung AL, Anderson KC, Ghobrial IM, Lin CP. Optical techniques for tracking multiple myeloma engraftment, growth, and response to therapy. J Biomed Opt 2011;16(1):011006.

[71] Chang YS, di Tomaso E, McDonald DM, Jones R, Jain RK, Munn LL. Mosaic blood vessels in tumors: frequency of cancer cells in contact with flowing blood. Proc Natl Acad Sci USA 2000;97(26):14608-13.

[72] Méhes G, Witt A, Kubista E, Ambros PF. Circulating breast cancer cells are frequently apoptotic. Am J Pathol 2001;159(1):17-20.

[73] Galanzha El, Shashkov EV, Kelly T, Kim JW, Yang L, Zharov VP. In vivo magnetic enrichment and multiplex photoacoustic detection of circulating tumour cells. Nat Nanotechnol 2009;4(12):855-60.

[74] Galanzha El, Shashkov EV, Spring PM, Suen JY, Zharov VP. In vivo, noninvasive, label-free detection and eradication of circulating metastatic melanoma cells using two-color photoacoustic flow cytometry with a diode laser. Cancer Res 2009;69(20):7926-34.

[75] Alt C, Veilleux I, Lee H, Pitsillides CM, Côté D, Lin CP. Retinal flow cytometer. Opt Lett 2007;32(23):3450-2. 